УДК 811.111

DOI https://doi.org/10.14258/zosh(2020)2.2

\title{
SUBSTANTIATION OF THE RISK OF HOOKAH USE BY STUDENTS
}

\section{Pats Natalia Viktorovna ${ }^{A B C D}$}

Ph. D. (candidate of medical Sciences), associate Professor of the Department of General hygiene and ecology Educational institution "Grodno State Medical University" (Grodno, Belarus), e-mail: pats_ nataly.2003@mail.ru. ORCID: https://orcid.org/0000-0001-6489-2851

\section{Romanova Elena Veniaminovna ${ }^{C D}$}

Candidate of Philosophy, Associate Professor, Associate Professor of the Department of Physical Education of the Altai State University Federal State Budgetary Educational Institution of Higher Education (Barnaul, Russia), e-mail: romanovaev.2007@mail.ru. ORCID: https://orcid.org/0000-00034317-605X

\section{Siniahub Ivan Sergeevich ${ }^{A B C}$}

student Grodno State Medical University. Grodno, Belarus. E-mail: feliix1105@tut.by

\section{ОБОСНОВАНИЕ РИСКА УПОТРЕБЛЕНИЯ КАЛЬЯНА СТУДЕНТАМИ}

\section{Пац Наталия Викторовна ${ }^{A B C D}$}

кандидат медицинских наук, доцент кафедры общей гигиены и экологии. Гродненский государственный медицинский университет» (Гродно, Беларусь). E-mail: pats_nataly.2003@mail.ru. ORCID: https://orcid.org/ 0000-0001-6489-2851

\section{Романова Елена Вениаминовна ${ }^{B C D}$}

кандидат философских наук, доцент, доцент кафедры физического воспитания Федерального государственного бюджетного образовательного учреждения высшего образования «Алтайский государственный университет» (Барнаул, Россия), e-mail: romanovaev.2007@mail.ru. ORCID: https://orcid.org/0000-0003-4317-605X

\section{Синегуб Иван Сергеевич ${ }^{A B C}$}

Студент. Гродненский государственный медицинский университет» (Гродно, Беларусь).

E-mail: feliix1105@tut.by 
ISSN 2414-0244 • Здоровье человека, теория и методика физической культуры и спорта • 2020. №2(18)

Следует цитировать / Citation:

Pats N. V., Romanova E. V, Siniahub I.S. (2020). Substantiation of the risk of hookah use by students Health, Physical Culture and Sports, 2 (18), pp. 17-22 (in Russian). URL: http://journal.asu. ru/zosh/issue/archive. DOI https://doi.org/10.14258/zosh(2020)2.2

Пац Н. В., Романова Е. В., Синегуб И.С. Обоснование риска употребления кальяна студентами // Здоровье человека, теория и методика физической культуры и спорта. 2020. № 2 (18). C. 17-22 URL: http://journal.asu.ru/zosh/issue/archive http://journal.asu.ru/zosh/issue/archiveDOI https://doi.org/10.14258/zosh(2020)2.2

Поступило в редакцию / Submitted 15.05.2020

Принято к публикации / Accepted 29.05.2020

Abstract. The purpose of this work was to assess the conditions conducive to the development of bad habits (hookah Smoking) and the risk of health disorders amongst the youth, and furthermore, the study of the amount of harmful substances entering the organism of a hookah smoker for 1 minute when smoking.

The questionnaire method with the use of original, author's electronic test questionnaires for medical and social picture of hookah consumers among young people is applied. The study was held in October 2019. The study involved 254 people, hookah smokers, among them 59 boys and 195 girls.

20 people were assessed the load obtained by the number of puffs, the volume of inhaled hookah smoke, and the duration of one puff in order to substantiate the risk of entering harmful substances, such as nitrosamines, polycyclic aromatic hydrocarbons, volatile aldehydes, benzene, nitrogen oxide, heavy metals, carbon monoxide in hookah smoker's organism for 1 minute.

It is revealed that not only youth, but also teenagers join hookah smoking. The frequency of hookah Smoking by young people is different: $24,3 \%$ of students smoke hookah every six months, $23,4 \%$ - once a quarter, 30, 9\% join the hookah Smoking only once a year, but there was a group of $20.6 \%$ out of the surveyed that consumes hookah once a month and more often.

The reasons why teenagers and young people smoke hookah are different: $22,6 \%$ of the respondents search for the opportunity to relax when Smoking hookah, consciously for personal pleasure $-38,7 \%$, only to support the company $-29,9 \%$.

On average hookah Smoking consists of 171 puffs of $530 \mathrm{ml}$ with the duration of one puff 3 seconds at a frequency of 2.8 puffs per minute.

The number of potentially dangerous components contained in hookah smoke, which has in its composition nitrosamines, polycyclic aromatic hydrocarbons, volatile aldehydes, benzene, nitric oxide, heavy metals, carbon monoxide, is quite high. This is a risk of health disorders in the young, unformed body of the hookah consumer, but it is also a risk of disturbance of the smoker's reproductive health, which has further long-term consequences for the future generation.

Keywords: hookah, volume of a puff, hookah smoke, risks, health, youth.

Аннотация: Цель данной работы состояла в том, чтобы оценить условия, способствующие развитию вредных привычек (курение кальяна), и риск нарушений здоровья среди молодежи, и, кроме того, изучение количества вредных веществ, поступающих в организм курильщика кальяна за 1 минуту при курении.

Применен метод анкетирования с использованием оригинальных авторских электронных тестовых анкет для медицинской и социальной картины потребителей кальяна среди молодежи. Исследование было проведено в октябре 2019 г. В исследовании приняли участие 254 человека, курящих кальян, среди которых 59 мальчиков и 195 девочек.

20 человек оценили нагрузку, полученную по количеству затяжек, объему вдыхаемого дыма для кальяна и продолжительности одной затяжки, чтобы обосновать риск попадания вредных веществ, таких как нитрозамины, полициклические ароматические углеводороды, 
летучие альдегиды, бензол, окись азота, тяжелые металлы, окись углерода в организме курильщика кальяна за 1 минуту.

Выявлено, что не только молодежь, но и подростки присоединяются к курению кальяна. Частота курения кальяна среди молодежи разная: $24,3 \%$ студентов курят кальян каждые шесть месяцев, 23,4\% - раз в квартал, 30,9\% присоединяются к курению кальяна только один раз в год, но была группа 20,6\% из опрошенных, которые употребляют кальян раз в месяц и чаще.

Причины, по которым подростки и молодые люди курят кальян, различны: 22,6\% респондентов ищут возможность расслабиться, когда курят кальян, сознательно для личного удовольствия $-38,7 \%$, только для поддержки компании $-29,9 \%$.

В среднем курение кальяна состоит из 171 затяжки по 530 мл с продолжительностью одной затяжки 3 секунды с частотой 2,8 затяжки в минуту.

Количество потенциально опасных компонентов, содержащихся в кальянном дыме, в состав которого входят нитрозамины, полициклические ароматические углеводороды, летучие альдегиды, бензол, оксид азота, тяжелые металлы, окись углерода, достаточно велико. Это риск возникновения расстройств здоровья в молодом, не сформированном теле потребителя кальяна, но это также риск нарушения репродуктивного здоровья курильщика, что имеет дальнейшие долгосрочные последствия для будущего поколения.

Ключевые слова: кальян, объем пуфа, кальянный дым, риски, здоровье, молодость.

$\mathrm{I}$

\section{NTRODUCTION}

Amongst the youth, it remains relevant to study the addiction of young people to bad habits. The main harmful habit in the age group from 17 to 20 years was tobacco Smoking $[1,6,9]$. But in the last 5 years, the amount of adherents of classical tobacco Smoking has shrunk, especially among students of higher educational institutions of medical specialties [2,3]. However, it should be noted that with increasing pace the introduction of young people, including students, to Smoking hookah is growing $[7,8]$. There are works of foreign scientists [8] indicating the Toxicological component of this bad habit $[4,5]$. It is noted that 1 gram of tobacco contains: resin- $802 \mathrm{mg}$, nicotine-2.96 mg, carbon monoxide (CO) -143 mg.

With a lot of work carried out in Belarus and Russia on the formation of adolescents and youth health-saving world view and behavior $[10,11]$ data on the number of young people who use hookah in Belarus, in open sources is not noted. Risk groups have not been studied. There is no data on the impact of hookah on the health of different age groups (adolescents and youth), and therefore relevant assessment of the risk of hookah use for adolescents and youth.
Purpose and objectives of the study. Therefore, the purpose of this work was to assess the conditions conducive to the development of bad habits (hookah Smoking) and the risk of health disorders amongst the youth, and furthermore, the study of the amount of harmful substances entering the organism of a hookah smoker for 1 minute when Smoking.

The study involved 254 people, including boys -59 , girls -195 , who smoke hookah.

The respondents' gender is predominantly female (195 people) (fig.1).

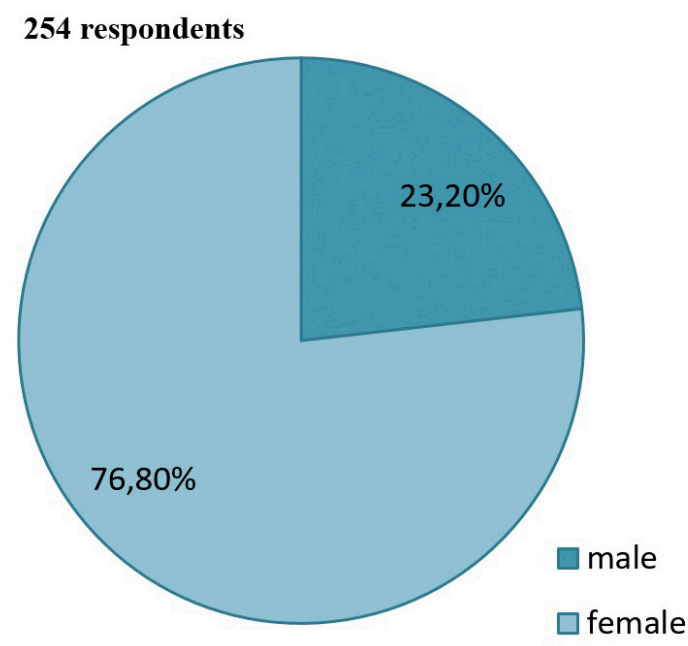

Fig. 1. Respondents' gender 
The respondents' age is chiefly $18-20$ years old (fig. 2). These are primarily students in the secondthird years (fig. 3 ).

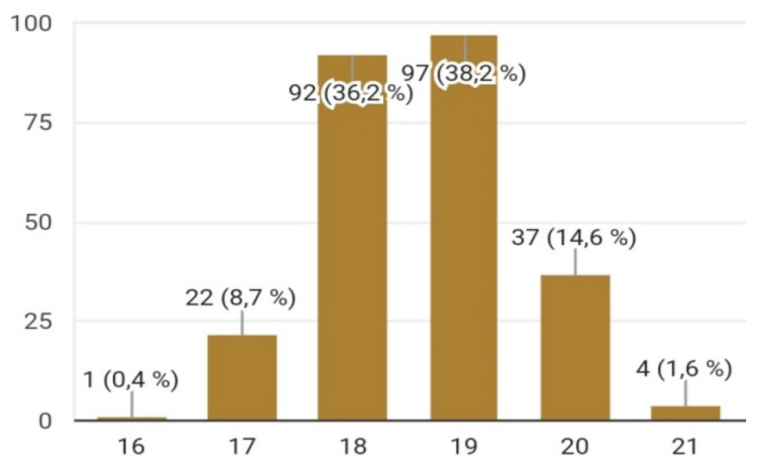

Fig. 2. Distribution of respondents according to the age

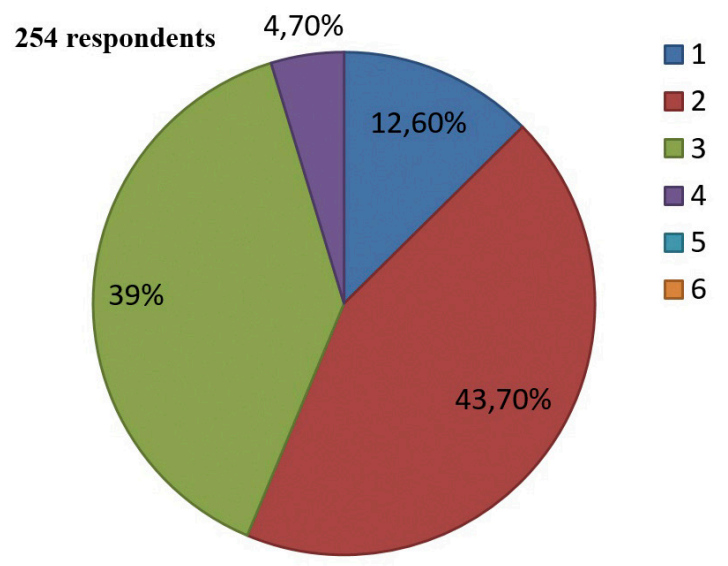

Fig. 3. Respondents year of study

However, a group of teenagers who are attached to Smoking Shisha was revealed. It was $9,1 \%$ of the surveyed.

\section{Materials and methods}

The questionnaire method is applied with the use of original, author's electronic test questionnaires on the questions reflecting the influence of the social environment on the development of bad habits (hookah Smoking). The study was conducted in October 2019.

A group of 20 people, who smoke hookah, was selected. They were estimated the load obtained by the number of puffs, inhaled volume of hookah smoke, and the duration of one puff to substantiate the risk of entering harmful substances such as nitrosamines, polycyclic aromatic hydrocarbons (PAHs, e. g., anthracene and benzopyrene), volatile aldehydes (e.g., formaldehyde, acetaldehyde, acrolein), benzene, nitrogen oxide, heavy metals (arsenic, chromium, lead), carbon monoxide (CO) in the hookah smoker's organism for 1 minute.

Statistical processing of the results was performed using software package Statistics 10.0

\section{Discussion and results.}

Studies have shown that the frequency of hookah Smoking by respondents is different. Thus, $24,3 \%$ of students smoke hookah every six months, $23,4 \%$ - once a quarter, $30,9 \%$ join the hookah Smoking only once a year, but there was a group of $20.6 \%$ out of the surveyed that consumes hookah once a month and more often (fig. 4).

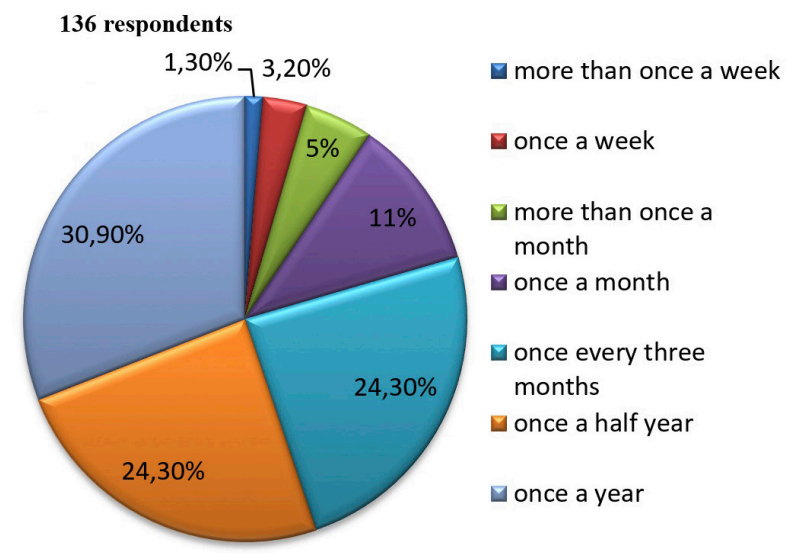

Fig. 4. Frequency of hookah Smoking by respondents

At the same time, it was found out whether our respondents smoke classical cigarettes, apart from the hookah. The survey showed with a high degree of certainty that no (fig. 5), and only $26,2 \%$ of the respondents smoke constantly, $7,4 \%$ of the respondents sometimes allow themselves to smoke 1-2 cigarettes.

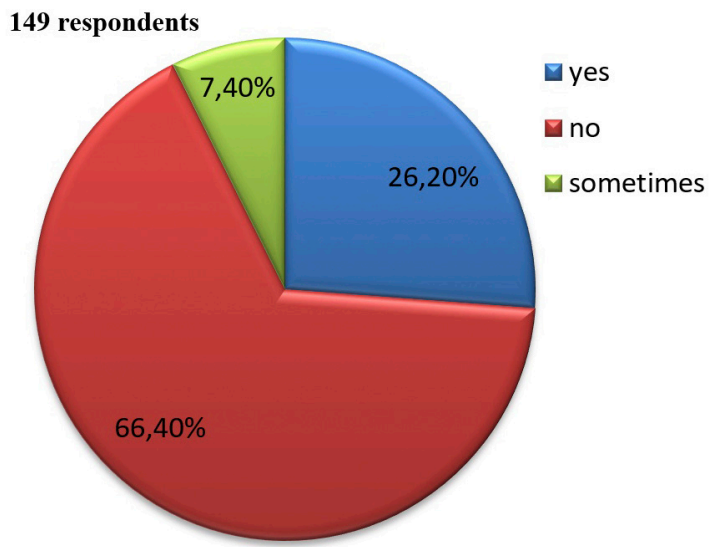

Fig. 5. Frequency of cigarette smoking in a group of students 
Members of the examined group of students Smoking hookah $(\mathrm{p}<0,05)$ chose chiefly the strength of medium tobacco, 36\% - light (fig. 6).

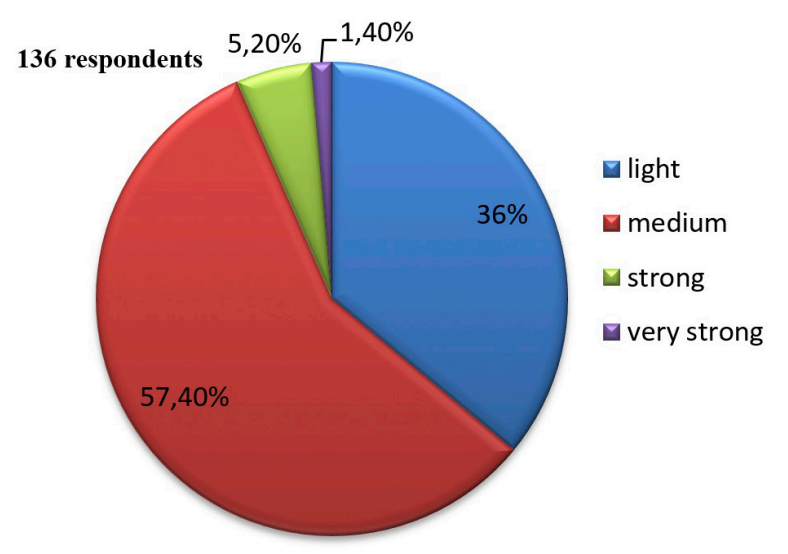

Fig. 6. Tobacco strength for hookah, chosen by respondents

When figuring out the reasons why respondents smoke hookah, it was noted that 22 , $6 \%$ of the respondents search for an opportunity to relax when Smoking hookah, consciously for personal pleasure $-38,7 \%$, only to support the company $-29,9 \%$. (fig. 7). It should be noted that hookah Smoking is promoted by various aromatic additives added to hookah tobacco, such as mango, apple, orange, pear and others.

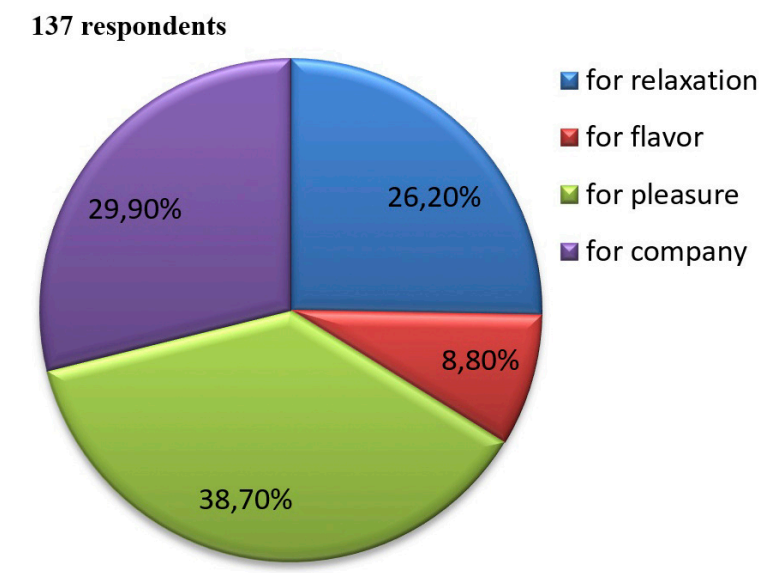

Fig. 7. Reasons for Smoking hookah by respondents

In the group of 20 examined people, when assessing the load which they received when using a hookah by the number of puffs, the volume of inhaled hookah smoke, and the duration of one puff, it was revealed that on average, Smoking a hookah consists of 171 puffs of $530 \mathrm{ml}$ with a duration of one puff of 3 seconds at a frequency of
2.8 puffs per minute. This model is based on data from Smoking sessions lasting 30 minutes and more (on average 60 minutes).

According to some researchers, the nicotine content of hookah tobacco ranges from $2 \%$ to $4 \%$ compared to $1 \%$ to $3 \%$ for cigarettes [5]. Other studies show that after hookah Smoking there is an increase in the level of nicotine and alcoloid (cotinine) [12]. According to these data, «after one 45-minute session of Smoking, the average concentration of nicotine in plasma increased from 1.11 to $60.31 \mathrm{ng} / \mathrm{ml}$, and cotinine - from 0.79 to $51.95 \mathrm{ng} / \mathrm{ml}$. The concentration of nicotine in saliva increased from 1.05 to $624.74 \mathrm{ng} / \mathrm{ml}$, and cotinine - from 0.79 to $283.49 \mathrm{ng} / \mathrm{ml}$. The average amount of nicotine and cotinine excreted in a 24-hour urine sample after Smoking was 73.59 mcg and $249 \mathrm{mcg}$, respectively» [12].

Thus, the results showed that the number of potentially dangerous components contained in hookah smoke, which has in its composition nitrosamines, polycyclic aromatic hydrocarbons (PAHs, for example, benzopyrene and anthracene), volatile aldehydes (for example, formaldehyde, acetaldehyde, acrolein), benzene, nitric oxide, heavy metals (arsenic, chromium, lead), carbon monoxide (CO) is quite high.

This is not only a risk of health disorders in the young, unformed body of the hookah consumer, but it is also a risk of disturbance of smoker's reproductive health, which has further long-term consequences for the future generation.

\section{CONCLUSION}

1. Not only youth audience, but also teenagers are involved in hookah Smoking.

2. The reasons why teenagers and young people smoke hookah are different: $22,6 \%$ of the respondents search for an opportunity to relax when Smoking hookah, consciously for personal pleasure $-38,7 \%$, only to support the company $29,9 \%$.

3. Hookah Smoking by youth is carried out with a frequency of every six months $-24,3 \%$ of students, once a quarter $-23,4 \%, 30,9 \%$ students join hookah Smoking only once a year, but out of the surveyed a group of $20.6 \%$ stood out, who consumes hookah once a month and more often.

4. On average, hookah Smoking among young people consists of 171 puffs of $530 \mathrm{ml}$ with a 
duration of one puff of 3 seconds at a frequency of 2.8 puffs per minute.

5. The number of potentially dangerous components contained in hookah smoke, which has in its composition nitrosamines, polycyclic aromatic hydrocarbons, volatile aldehydes, benzene, nitric oxide, heavy metals, carbon monoxide, is high enough that with the volume of inhaling and their number per minute presents a toxicological risk of health disorders in a young, unformed body not only for the hookah consumer, but also is a risk of disturbance of smoker's reproductive health, which has further long-term consequences for the future generation.

\section{BIBLIOGRAPHIC REFERENCES.}

1. Astapenko, A., Antiperovich T. (2012). Tobacco - stroke. Health and success, 5. - pp. 9-10.

2. Çuperjani F. [et al.] Tobacco Smoking Habits Among First Year Medical Students, University of Prishtina, Kosovo: Cross-sectional Study. Mater Sociomed, 27 (3), pp. 176-179.

3. Gorbunov N.V., Polunina O.S., Serdyukov A. G. (2012). Sociological study of the problem of tobacco Smoking among medical students. Kuban scientific medical Bulletin, 3 (132). pp. 41-44.

4. Jabbour S, El-Roueiheb Z, Sibai A. M. (2003). Narghile (water-pipe) smoking and incident coronary heart disease: a case-control study [abstract]. Ann Epidemiol, 13, P.570.

5. Kiter G, Ucan ES, Ceylan E, Kilinc O. (2000). Water-pipe smoking and pulmonary functions. Respir Med., 94, pp.891-894.

6. Makarova [et al.] (2014). Smoking among young people: frequency, effect on lung function and serum level of soluble adhesion molecules. Archive of internal medicine, 2 (16). pp. 60-63.

7. Maziak W, Eissenberg T, Rastam S, et al. (2004). Beliefs and attitudes related to narghile (waterpipe) smoking among university students in Syria. Ann Epidemiol, 14, pp. 646-654

8. Memon A, Moody PM, Sugathan TN, et al. (2000). Epidemiology of smoking among Kuwaiti adults: prevalence, characteristics and attitudes. Bull WH, 78, pp. 1306-1315

9. Pats, N. V. (2014). Valeologo-hygienic approaches to risk assessment and prevention: healthdestroying behavior among children, adolescents and youth. Science 2020, 1, pp. 4-7

10. Pats, N. V. (2014). Improvement of approaches to diagnosis and prevention of modern problems of healthy lifestyle formation at industrial enterprises. Achievements of biology and medicine, 2, pp. 78-84.

11. Romanova, E. V. (2014). Health of youth in the aspect of the study of addictive behaviors / / human Health, theory and methodology of physical culture and sports, 2, pp. 14-24, URL: http://journal. asu.ru/zosh/article/view/1622

12. Shafagoj YA, Mohammed FI, Hadidi KA. (2002). Hubble-bubble (water pipe) smoking: levels of nicotine and cotinine in plasma, saliva and urine. Int J Clin Pharmacol Ther., 40, pp. 249-255 